\title{
Phytophagous insects and natural enemies in kale under organic and chemical fertilizers
}

\section{Insetos fitófagos e inimigos naturais em couve sob adubação orgânica e química}

\author{
Francisco Jorge Cividanes ${ }^{1 *}$ (D) (orcid.org/0000-0002-6911-671X) \\ Karen Pereira da Silva ${ }^{2}$ (D) (orcid.org/0000-0003-0253-640X) \\ Ivan Carlos Fernandes Martins ${ }^{3}$ (D) (orcid.org/0000-0002-4405-2713) \\ Terezinha Monteiro dos Santos Cividanes' (D) (orcid.org/0000-0003-4178-0181)
}

\begin{abstract}
Organic agriculture is distinguished by practices that benefit the environment and support sustainable agriculture. In the present study, leafy kale, Brassica oleracea L. var. acephala DC., was submitted to chemical and organic (castor bean cake and bovine manure) fertilization treatments aiming to verify the influence of these fertilizers on the occurrence of insect pests and natural enemies. The insects were sampled by visual examination of plants and pitfall traps. Brevicoryne brassicae (L.) and Myzus persicae (Sulzer) (Hemiptera: Aphididae) were the phytophagous insects that occurred more significantly in kale, under chemical rather than organic fertilization, whereas Harmonia axyridis (Pallas), Hippodamia convergens (Guérin-Méneville) (Coleoptera: Coccinellidae), Diaeretiella rapae (M'Intosh) (Hymenoptera: Braconidae) and spiders (Arachnida: Araneae) were abundant in kale under organic fertilizer. The study showed that castor bean cake and bovine manure as leafy kale fertilizers can reduce the use of insecticides and provide quality food.
\end{abstract}

KEYWORDS: family farming; Brassica oleracea; biological control; fertilizers; sustainability.
RESUMO: A agricultura orgânica destaca-se pelo emprego de práticas que beneficiam o meio ambiente e aumentam a sustentabilidade na agricultura. No presente estudo, a couve-de-folha, Brassica oleracea L. var. acephala DC., foi submetida a tratamentos de adubação química e orgânica à base de torta de mamona e esterco bovino para se verificar a influência dos fertilizantes na ocorrência de insetos pragas e inimigos naturais. Os insetos foram amostrados por meio de exame visual de plantas e armadilhas tipo alçapão. Brevicoryne brassicae (L.) e Myzus persicae (Sulzer) (Hemiptera: Aphididae) foram os insetos fitófagos que ocorreram significativamente em maior número em couve sob adubação química que orgânica, enquanto Harmonia axyridis (Pallas), Hippodamia convergens (Guérin-Méneville) (Coleoptera: Coccinellidae), Diaeretiella rapae (M'Intosh) (Hymenoptera: Braconidae) e aranhas (Arachnida: Araneae) foram abundantes em couve sob adubo orgânico. $\mathrm{O}$ estudo evidenciou que o uso de torta de mamona e esterco bovino como adubo de couve-de-folha pode reduzir o uso de inseticidas e fornecer alimentos de qualidade.

PALAVRAS-CHAVE: agricultura familiar; Brassica oleracea; controle biológico; fertilizantes; sustentabilidade. 


\section{INTRODUCTION}

Vegetables of the family Brassicaceae, Brassica oleracea L., are considered a food eaten routinely and in quantities that constitute an important portion of people's diets in many parts of the world. The leafy kale, Brassica oleracea L. var. acephala DC., stands out for its economic importance and high nutritional value (FILGUEIRA, 2008). Among the leafy vegetables, kale is widely grown in Brazil, especially in the state of São Paulo (TRANI et al., 2015; VILELA; LUENGO, 2017).

Pest damage is widely reported as one of the major problems that concerns kale growers. For example, the aphids Brevicoryne brassicae (L.) and Myzus persicae (Sulzer) (Hemiptera: Aphididae) cause high production losses and transmit diseases, and their presence may reduce production and crop quality (PICANÇO et al., 2000; HOLTZ et al., 2015). In fact, Myzus persicae can limit the commercial production of brassica vegetables, especially in organic systems (MORENO; RACELIS, 2015). Other insect pests that affect the production of kale are the whitefly, Bemisia tabaci (Genn.) (Hemiptera: Aleyrodidae), Ascia monuste orseis (Godart) (Lepidoptera: Pieridae), the diamondback moth, Plutella xylostella L. (Lepidoptera: Plutellidae), and the black cutworm, Agrotis ipsilon (Hufnagel) (Lepidoptera: Noctuidae) (HOLTZ et al., 2015).

The practices used in organic cropping systems for vegetable production benefit both the environment and cultivated plants (DELATE et al., 2003; SILVA et al., 2012). Organic fertilizers, for instance, not only improve soil characteristics, but are also related to the production of high-quality food without causing environmental problems (SILVA et al., 2012). The use of castor bean cake and bovine manure in agriculture is directly related to sustainable practices and family farming (PINTO et al., 2016). However, published studies on these organic fertilizers usually report only the effects on vegetable production (SANTOS et al., 2012; PINTO et al., 2016), with little information about their effects on pests and natural enemies.

Management of insect pests in organic systems requires knowledge of the interactions among organisms in agroecosystems to keep pests at low population levels (VENZON et al., 2015). Nonetheless, organic systems have some information gaps, because although these farming systems increase arthropod diversity, most of the behavioral responses of pests and natural enemies to these systems are unknown (GARRAT et al., 2011). The objective of this study was to quantify the populations of phytophagous insects and natural enemies in leafy kale submitted to chemical and organic fertilization to determine the effects of the fertilizers on these organisms.

\section{MATERIAL AND METHODS}

The study was carried out at Laboratório de Ecologia de Insetos (LECOL) and an experimental area located at Universidade
Estadual Paulista "Júlio de Mesquita Filho", Jaboticabal

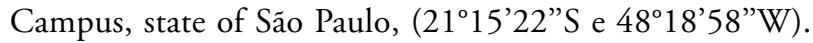
The soil is classified as Oxisol.

Two treatments were distributed in a completely randomized design containing 10 replications. Each sampling plot had 16 square meters $(4 \times 4 \mathrm{~m})$, each containing four rows of leafy kale, $B$. oleracea var. acephala, Geórgia cultivar, manually transplanted at $0.5 \mathrm{~m}$ (within row) $\times 1.0 \mathrm{~m}$ (between row) spacing, in April $16^{\text {th }}, 2010$. Treatments included the following: Treatment $1=$ chemical fertilizer $\left(3.2 \mathrm{~kg} /\right.$ plot or $200 \mathrm{~g} / \mathrm{m}^{2}$ of the 20-20-20 NPK formula); and Treatment 2 = organic fertilizer $\left(80 \mathrm{~kg} /\right.$ plot or $5 \mathrm{~kg} / \mathrm{m}^{2}$ of the mixture of bovine manure and castor bean cake in a 4:1 ratio).

Insects were sampled by visual examination and pitfall traps, from April to November 2010. The visual examination was carried out at weekly intervals, totaling 33 sampling dates, performed by randomly selecting 5 plants located in the center of a plot and collecting insects using plastic tubes of $8 \mathrm{~cm}$ high and a $2 \mathrm{~cm}$ diameter. Aphids were sampled considering a circular area of a $3.5 \mathrm{~cm}$ diameter of a leaf surface, as described by SOUSA (1990). Pitfall traps were $500 \mathrm{~mL}, 80 \mathrm{~mm}$ diameter plastic cups, containing $50 \mathrm{~mL}$ of a solution of formaldehyde in water (1\%) and detergent. Traps were covered with a plastic roof (diameter $200 \mathrm{~mm}$ ) to protect them from litter and rain. One trap was installed in the center of each plot and was emptied and serviced biweekly during the study period, totaling 15 sampling dates. At each sampling date, traps were set and remained in the field for 7 days. The coccinellids were identified to species level by Terezinha Monteiro dos Santos Cividanes, Instituto Biológico, city of Ribeirão Preto, state of São Paulo. Aphids, spiders and other insects were identified by comparison with specimens deposited in Coleçáo de Arthropodes do LECOL, Universidade Estadual Paulista "Júlio de Mesquita Filho", city of Jaboticabal, state of São Paulo.

All data were subjected to analysis of variance and Tukey test $(\mathrm{p} \leq 0.05)$. Here, we considered the total insect individuals captured in the 5 plants/plot and the total number of aphids (nymphs and adults) recorded on the leaf surface. For soildwelling insects, the total number of individuals captured in the traps was considered. Data were transformed $(\log (x+1))$ prior to analysis.

\section{RESULTS AND DISCUSSION}

A total of three orders of insects (Coleoptera, Hemiptera and Hymenoptera) and spiders (Arachnida: Araneae) were captured. Most of them (97.2\%) consisted of phytophagous insects, which were more numerous in chemically fertilized kale, whereas natural enemies prevailed in plants under castor bean cake and bovine manure fertilization (Table 1). 
Table 1. Average number of arthropods captured in leafy kale cultivated with chemical (Che) and organic (Org) fertilizers. Jaboticabal city (São Paulo), 2010.

\begin{tabular}{|c|c|c|c|}
\hline \multicolumn{2}{|c|}{ Sampling location/taxon } & Che & Org \\
\hline \multirow{26}{*}{ Leaves } & Coleoptera & & \\
\hline & Coccinellidae & & \\
\hline & Cycloneda sanguinea (L.) & 0.71 & 0.88 \\
\hline & Eriops conexa (Germar) & 0.19 & 0.29 \\
\hline & $\begin{array}{l}\text { Harmonia axyridis } \\
\text { (Pallas) }\end{array}$ & 1.16 & 2.38 \\
\hline & $\begin{array}{l}\text { Hippodamia convergens } \\
\text { (Guérin-Méneville) }\end{array}$ & 8.96 & 15.93 \\
\hline & Chrysomelidae & & \\
\hline & $\begin{array}{l}\text { Diabrotica speciosa } \\
\text { (Germar) }\end{array}$ & 0.23 & 0.31 \\
\hline & Elateridae & & \\
\hline & Heteroderes sp. & 0.03 & 0.07 \\
\hline & Lagriidae & & \\
\hline & Lagria villosa (Fabr.) & 0.07 & 0.19 \\
\hline & Hemiptera & & \\
\hline & Aleyrodidae & & \\
\hline & Bemisia tabaci (Genn.) & 31.13 & 40.24 \\
\hline & Aphididae & & \\
\hline & Brevicoryne brassicae (L.) & 372.17 & 299.24 \\
\hline & Myzus persicae (Sulzer) & 726.56 & 512.67 \\
\hline & Cydinidae & & \\
\hline & $\begin{array}{l}\text { Scaptocoris } \\
\text { castanea (Perty) }\end{array}$ & 0.12 & 0.41 \\
\hline & Hymenoptera & & \\
\hline & Formicidae & 0.99 & 1.44 \\
\hline & Braconidae & & \\
\hline & $\begin{array}{l}\text { Bracon lizerianus } \\
\text { (Blanchard) }\end{array}$ & 0.20 & 0.41 \\
\hline & $\begin{array}{l}\text { Diaeretiella } \\
\text { rapae (M'Intosh) }\end{array}$ & 0.59 & 2.09 \\
\hline & Araneae & 7.38 & 14.27 \\
\hline \multirow{10}{*}{ Soil } & Coleoptera & & \\
\hline & Alleculidae & 0.17 & 0.31 \\
\hline & Carabidae & & \\
\hline & Abaris basistriata Chaudoir & 0.00 & 0.03 \\
\hline & Galerita brasiliensis Dejean & 0.04 & 0.03 \\
\hline & Lebia sp. & 0.01 & 0.00 \\
\hline & Scarites sp. & 0.02 & 0.01 \\
\hline & $\begin{array}{l}\text { Selenophorus alternans } \\
\text { Dejean }\end{array}$ & 0.00 & 0.01 \\
\hline & $\begin{array}{l}\text { Selenophorus } \\
\text { discopunctatus Dejean }\end{array}$ & 0.00 & 0.10 \\
\hline & $\begin{array}{l}\text { Tetracha brasilienis } \\
\text { (Kirby) }\end{array}$ & 0.03 & 0.00 \\
\hline
\end{tabular}

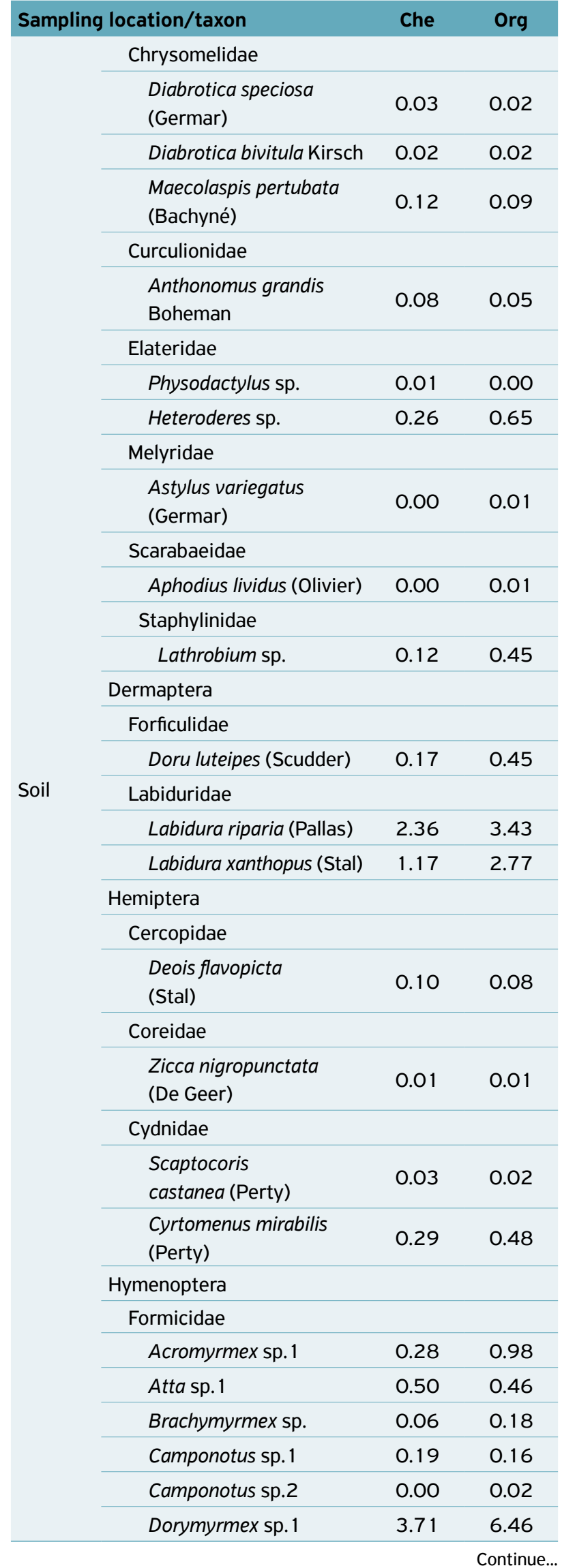


Table 1. Continuation.

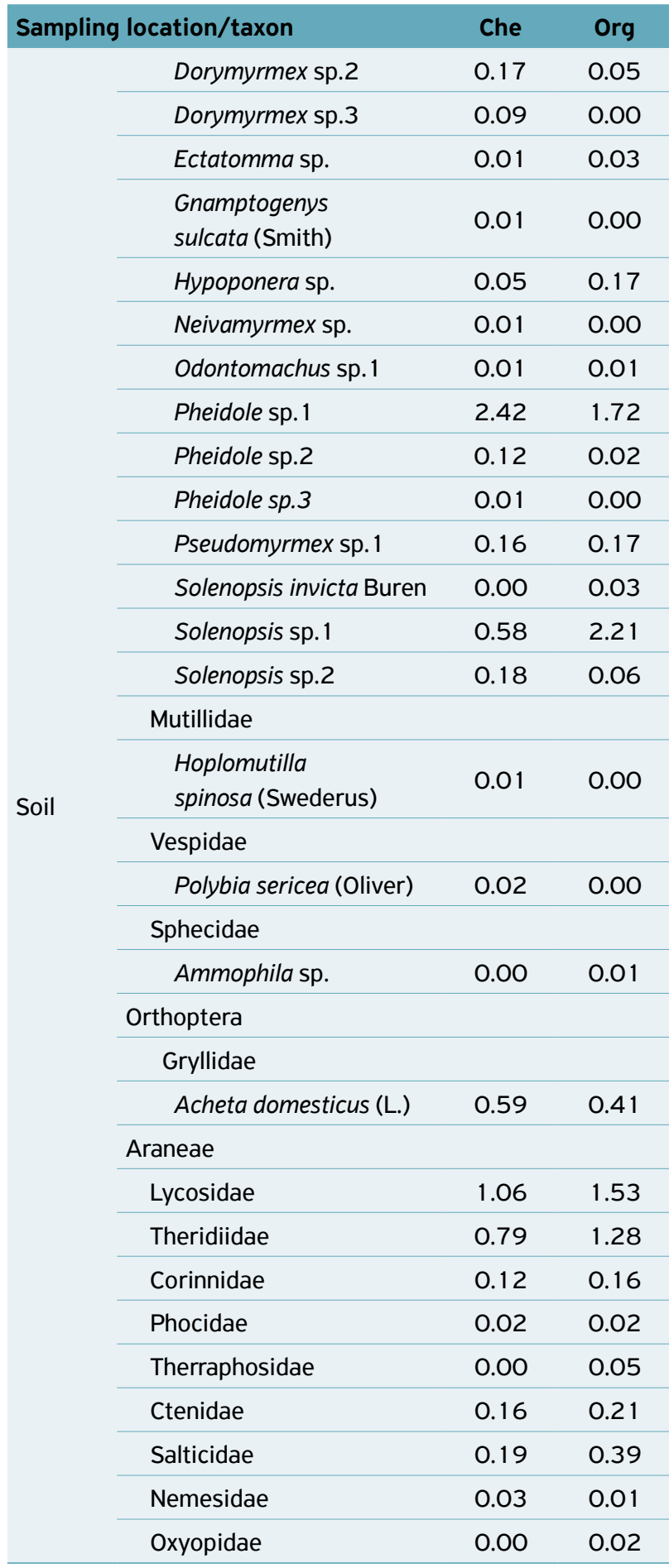

The aphids $B$. brassicae and $M$. persicae were the most numerous phytophagous insects when plants were fertilized with chemical fertilizer, followed by the whitefly Bemisia tabaci biotype B (Genn.) (Hemiptera: Aleyrodidae); but, in this case, there was no statistically significant difference between treatments (Table 2). On the other hand, Hippodamia convergens (Guérin-Méneville), Harmonia axyridis (Pallas) (Coleoptera:
Coccinellidae), Diaeretiella rapae (M'Intosh) (Hymenoptera: Braconidae) and spiders were natural enemies that occurred significantly more often in kale under the organic fertilizer (Table 2). Ladybugs accounted for $51.7 \%$ of these natural enemies, and $H$. convergens was the most numerous species followed by H. axyridis, Cycloneda sanguinea (L.) and Eriopis connexa (Gemar). Coccinellids have potential as biological control agents of agricultural insect pests (GONZÁLEZ, 2014). For example, $H$. axyridis and $H$. convergens are effective aphid predators (RICE; WILDE, 1988; FLINT; DREISTADT, 2005; RAMOS et al., 2017), whereas the greenbug, Schizaphis graminum (Rondani), has been effectively controlled by $H$. convergens, $C$. sanguinea and $E$. connexa in vegetables and other crops (FIORENTIN et al., 2013). Araneae and D. rapae are considered important natural enemies associated with kale. Araneae was considered a significant mortality factor of $B$. brassicae in relation to several predatory ant species, including Solenopsis spp. (CIVIDANES, 2002), whereas D. rapae was indicated as the dominant natural enemy in kale, and have the potential to control aphids (BUENO; SOUZA, 1993; CIVIDANES, 2002).

In the present study, the significantly low number of $B$. brassicae and $M$. persicae found in leaves of kale plants under organic fertilization can probably be related to the action of natural enemies, such as $D$. rapae, spiders and especially ladybugs (Table 2). The high number of aphids and, especially, the low number of natural enemies observed in kale under chemical fertilization in comparison to the abundance of these insects found in organically fertilized plants provide further evidence that castor bean cake and bovine manure favored the occurrence of natural enemies. These results are consistent with STALEY et al. (2010), who reported that the diamondback moth, P. xylostella, and the green peach aphid, $M$. persicae, were more numerous in Brassicaceae plants cultivated in soil under chemical fertilization than in those cultivated in soil fertilized with animal manure.

Arthropods captured with pitfall traps represented six orders of insects and spiders (Table 1). Phytophagous insects and natural enemies occurred in high density in plants cultivated with chemical and organic fertilizers, respectively, which is a similar result for insects found in kale leaves. However, natural enemies represented $85.6 \%$ of the soil-inhabiting individuals, the opposite of the composition of insects observed in kale leaves.

Heteroderes sp. (Coleoptera: Elateridae) was significantly more numerous in kale under organic fertilization (Table 2). Generally, adult elaterids are phytophagous insects. Although there are no records of Heteroderes damaging kale plants, some species of Heteroderes are considered pests of peanut, sugarcane and oilseed crops (MORRIS; WATERHOUSE, 2001; SAMSON; CALDER, 2003).

Ants (Formicidae), earwigs (Dermaptera) and spiders (Araneae) were predatory arthropod groups that prevailed 
Table 2. Number (mean \pm standard error) of phytophagous insects and natural enemies captured in kale under chemical (Che) and organic (Org) fertilizers. Jaboticabal city (São Paulo), 2010.

\begin{tabular}{|c|c|c|c|c|c|}
\hline \multicolumn{2}{|c|}{ Sampling location/taxon } & Che & Org & $\mathbf{F}$ & CV (\%) \\
\hline \multirow{12}{*}{ Leaves } & Coleoptera & & & & \\
\hline & Coccinellidae & & & & \\
\hline & Harmonia axyridis (Pallas) & $1.16 \pm 1.1 b^{1}$ & $2.38 \pm 1.6 a$ & $8.41^{* *}$ & 12.5 \\
\hline & Hippodamia convergens (Guérin-Méneville) & $8.96 \pm 3.2 b$ & $15.93 \pm 4.2 a$ & $32.25^{* *}$ & 4.4 \\
\hline & Hemiptera & & & & \\
\hline & Aphididae & & & & \\
\hline & Brevicoryne brassicae (L.) & $372.17 \pm 20.3 a$ & $299.24 \pm 18.2 b$ & $5.11 *$ & 2.6 \\
\hline & Myzus persicae (Sulzer) & $726.56 \pm 28.4 a$ & $512.67 \pm 23.9 b$ & $9.94^{* *}$ & 2.9 \\
\hline & Hymenoptera & & & & \\
\hline & Braconidae & & & & \\
\hline & Diaeretiella rapae (M'Intosh) & $0.59 \pm 0.8 b$ & $2.09 \pm 1.5 a$ & $52.08^{* *}$ & 9.8 \\
\hline & Araneae & $7.38 \pm 2.9 b$ & $14.27 \pm 4.0 a$ & $150.25^{\star *}$ & 2.4 \\
\hline \multirow{11}{*}{ Soil } & Coleoptera & & & & \\
\hline & Carabidae & & & & \\
\hline & Selenophorus discopunctatus Dejean & $0.0 \pm 0.0 b$ & $0.10 \pm 0.3 a$ & $6.88^{*}$ & 8.3 \\
\hline & Elateridae & & & & \\
\hline & Heteroderes sp. & $0.26 \pm 0.5 b$ & $0.65 \pm 0.9 a$ & $7.00^{*}$ & 15.2 \\
\hline & Hymenoptera & & & & \\
\hline & Formicidae & & & & \\
\hline & Solenopsis sp. 1 & $0.58 \pm 0.8 b$ & $2.21 \pm 1.6 a$ & $9.73^{* *}$ & 21.2 \\
\hline & Araneae & & & & \\
\hline & Lycosidae & $1.06 \pm 1.1 b$ & $1.53 \pm 1.3 a$ & $7.67^{*}$ & 7.4 \\
\hline & Theridiidae & $0.79 \pm 0.9 b$ & $1.28 \pm 1.2 \mathrm{a}$ & $5.89 *$ & 11.0 \\
\hline
\end{tabular}

'Numbers followed by different letters in same line are different by Tukey test $(p<0.05)$; * ** significant at $p<0.05$ and $p<0.01$, respectively; numbers are not transformed to $(\log x+5)$.

among those captured in the soil (Table 1). Overall, Araneae (Lycosidae and Theridiidae), Solenopsis sp. 1 (Hymenoptera: Formicidae), and Selenophorus discopunctatus (Dejean) (Coleoptera: Carabidae) were significantly more numerous in organically fertilized plants than the chemically fertilized ones (Table 2). Although ants of the genus Solenopsis are considered agricultural pests (WOJCIK et al., 2001), some Solenopsis species are predators of small arthropods. For example, ROSSI; FOWLER (2002) reported that Solenopsis invicta (Buren) played a major role in suppressing a population of Diatraea saccharalis Fabr. (Lepidoptera: Crambidae). A marked reduction in D. saccharalis larvae in areas where ants of the genus Solenopsis have always been more numerous than other ant species was also observed (ROSSI; FOWLER, 2000). Carabids are recognized as predatory beetles inhabiting soils. Selenophorus species can feed on plant seeds (TOOLEY; BRUST, 2002) and larvae of Anticarsia gemmatalis Hübner (Lepidoptera: Erebidae) (CIVIDANES et al., 2014). In this study, the presence of $S$. discopunctatus, and even other carabid species in kale under organic fertilization (Tables 1 and 2), suggest that carabids may have acted as control agents of insect pests. Spiders (Araneae), as discussed above, acted as an important mortality factor of B. brassicae (CIVIDANES, 2002).

\section{CONCLUSIONS}

This study revealed that natural enemies occurred in higher numbers than insect pests, such as $B$. brassicae, $M$. persicae and $B$. tabaci in leafy kale organically fertilized with castor 
bean cake and bovine manure in comparison with kale under chemical fertilization. Thus, the use of these organic fertilizers should be encouraged among kale growers due to their potential to reduce the amount of insecticides, which have been used in the control of insect pests. In addition, the use of castor bean cake and bovine manure agrees with sustainable agriculture practices, and they also contribute to encouraging family farming and to obtain better quality food.

ACKNOWLEDGMENTS: We thank José Carlos Barbosa for his assistance with statistical analysis, and Conselho Nacional de Desenvolvimento Científico e Tecnológico (CNPq) (Process 304930/2009-1) for providing a scholarship to the first author.

FUNDING: This work was supported by the Conselho Nacional de Desenvolvimento Científico e Tecnológico (CNPq) (Process 304930/2009-1)

CONFLICTS OF INTEREST: All authors declare that they have no conflict of interest.

ETHICAL APPROVAL: Not applicable.

AVAILABILITY OF DATA AND MATERIAL: The datasets generated and/or analyzed during the current study are available from the corresponding author on reasonable request.

AUTHORS' CONTRIBUTIONS: Conceptualization: Cividanes, F.J.; Santos-Cividanes, T.M.S. Data curation: Silva, K.P.; Martins, I.C.F. Formal analysis: Silva, K.P.; Martins, I.C.F. Methodology: Cividanes, F.J.; Santos-Cividanes, T.M.S.; Martins, I.C.F. Writing - review \& editing: Cividanes, F.J.; Santos-Cividanes, T.M.S.

|||||||||||||||||||||||||||||||||||||||||||||||||||||||||||||||||||||||||||||||||||||||||||||||||||||||||||||||||||||||||||||||||||||||||||||||||||||||||||||||||||||||||||||||||||||||||||||||||||||||||||||||| REFERENCES

BUENO, V.H.P.; SOUZA, B.M. Ocorrência e diversidade de insetos predadores e parasitoides na cultura da couve Brassica oleraceae var. acephala em Lavras, MG, Brasil. Anais da Sociedade Entomológica do Brasil, Jaboticabal, v.22, n. 1, p.5-18, 1993.

CIVIDANES, F.J. Impacto de inimigos naturais e de fatores meteorológicos sobre uma população de Brevicoryne brassicae (L.) (Hemiptera: Aphididae) em couve. Neotropical Entomology, Londrina, v.31, n.2, p.249-255, 2002. http://dx.doi.org/10.1590/ S1519-566X2002000200012

CIVIDANES, F.J.; IDE, S.; RIBEIRO, A.A.; SANTOS-CIVIDANES, T.M. Potencial predatório de Carabidae e Staphylinidae (Coleoptera) sobre a lagarta-da-soja. Pesquisa Agropecuária Brasileira, Brasília, v.49, n.8, p.652-655, 2014. http://dx.doi.org/10.1590/ So $100-204 \times 2014000800010$

DELATE, K.; FRIEDRICH, H.; LAWSON, V. Organic pepper production systems using compost and cover crops. Biological Agriculture and Horticulture, v.21, n.2, p.131-150, 2003. https://doi.org/ 10.1080/01448765.2003.9755258

FILGUEIRA, F.A.R. Novo manual de olericultura: agrotecnologia moderna na produção e comercialização de hortaliças. 3. ed. Viçosa: UFV, 2008. $421 \mathrm{p}$.

FIORENTIN, F.J.R.; PINNO, S.; AVILA, A.R. Utilização de joaninhas no controle biológico de pulgões. Scientia Prima, São Paulo, v.1, n. 1, p.27-32, 2013.

FLINT, M.L.; DREISTADT, S.H. Interactions among convergent lady beetle (Hippodamia convergens) releases, aphid populations, and rose cultivar. Biological Control, London, v.34, n.1, p.3846, 2005. https://doi.org/10.1016/j.biocontrol.2005.03.019

GARRAT, M.P.D.; WRIGHT, D.J.; LEATHER, S.R. The effects of farming system and fertilizers on pests and natural enemies: a synthesis of current research. Agriculture, Ecosystems and Environment, Amsterdam, v.141, n.3-4, p.261-270, 2011. https://doi.org/10.1016/j.agee.2011.03.014

GONZÁLEZ, G. Coccinellidae. In: ROIG-JUÑENT, S.; CLAPS, L.E.; MORRONE, J.J. (Eds.) Biodiversidade de artrópodos argentinos. Tucumán: Universidade Nacional de Tucumán, 2014. p.509-530.

HOLTZ, A.M.; RONDELLI, V.M.; CELESTINO, F.N.; BESTETE, L.R.; CARVALHO, J.R. Pragas das brássicas. Colatina: IFES, 2015.230p.

MORENO, C.R.; RACELIS, A.E. Attraction, repellence, and predation: role of companion plants in regulating Myzus persicae (Sulzer) (Hemiptera: Aphididae) in organic kale systems of South Texas. Southwestern Entomologist, v.40, n.1, p.1-14, 2015. https:// doi.org/10.3958/059.040.0101

MORRIS, H.; WATERHOUSE, D.F. The distribution and importance of arthropod pests and weeds of agriculture in Myanmar. Canberra: ACIAR, 2001. Available from: <http://ageconsearch.umn.edu/ bitstream/1 14804/2/67.pdf>. Access on: Aug. 022018.

PICANÇO, M.; GUSMÃO, M.R.; GALVAN, T.L. Manejo integrado de pragas de hortaliças. In: ZAMBOLIM, L. (Ed.). Manejo integrado - doenças, pragas e plantas daninhas. Viçosa: UFV, 2000. p.275-324. 
PINTO, L.E.V.; GOMES, E.D.; SPÓSITO, T.H.N. Uso de esterco bovino e de aves na adubação orgânica da alface como prática agroecológica. Colloquium Agrariae, Presidente Prudente, v. 12 , n.especial, p.75-81, 2016. https://doi.org/10.5747/ca.2016. v12.nesp.000174

RAMOS, T.O.; SOUZA, L.S.; SANTOS-CIVIDANES, T.M.; CIVIDANES F.J. Joaninha asiática Harmonia axyridis (Pallas, 1773) (Coleoptera: Coccinellidae). Cerrado Agrociências, Patos de Minas, v.8, p. $116-124,2017$.

RICE, M.E.; WILDE, G.E. Experimental evaluation of predators and parasitoids in suppressing greenbugs (Homoptera: Aphididae) in sorghum and wheat. Environmental Entomology, Lanham, v.17, n.5, p.836-841, 1988.

ROSSI, M.N.; FOWLER, H.G. Ant predation of larval Diatraea saccharalis Fab. (Lep., Crambidae) in new sugarcane in Brazil. Journal of Applied Entomology, Berlin, v.124, n.5-6, p.245-247, 2000. http://dx.doi. org/10.1046/j.1439-0418.2000.00465.x

ROSSI, M.N.; FOWLER, H.G. Manipulation of fire ant density, Solenopsis spp., for short-term reduction of Diatraea saccharalis larval densities in Brazil. Scientia Agricola, Piracicaba, v.59, n.2, p.389-392, 2002. http://dx.doi.org/10.1590/ so $103-90162002000200027$

SAMSON, P.R.; CALDER, A.A. Wireworm (Coleoptera: Elateridae) identity, monitoring and damage in sugarcane. Australian Journal of Entomology, Bundaberg, v.42, n.3, p.298-303, 2003. https:// doi.org/10.1046/j.1440-6055.2003.00351.x

SILVA, S.D.; PRESOTTO, R.A.; MAROTA, H.B.; ZONTA, E. Uso de torta de mamona como fertilizante orgânico. Pesquisa Agropecuária Tropical, Goiânia, v.42, n.1, p.19-27, 2012. https:// doi.org/10.1590/S1983-40632012000100003

SANTOS, S.S.; ESPÍNDOLA, J.A.A.; GUERRA, J.G.M.; LEAL, M.A.A.; RIBEIRO, R.L.D. Produção de cebola orgânica em função do uso de cobertura morta e torta de mamona. Horticultura Brasileira
Brasília, v.30, n.3, p.549-552, 2012. http://dx.doi.org/10.1590/ so $102-05362012000300032$

SOUSA, B.M. Efeitos de fatores climáticos e de inimigos naturais sobre Brevicoryne brassicae (Linnaeus, 1758) (Homoptera: Aphididae) em couve Brassica oleracea var. acephala (DC.) (Catparales: Brassicae). $131 \mathrm{f}$. Dissertation (Master's Degree) - Universidade Federal de Lavras, Lavras, 1990.

STALEY, J.T.; STEWART-JONES, A.; POPE, T.W.; WRIGHT, D.J.; LEATHER, S.R.; HADLEY, P.; ROSSITER, J.T.; VAN EMDEN, H.F.; POPPY, G.M. Varying responses of insect herbivores to altered plant chemistry under organic and conventional treatments. Proceedings of the Royal Society B, v.277, n. 1682, p.779-786, 2010. https://doi.org/10.1098/rspb.2009.1631

TOOLEY, J.; BRUST, G.E. Weed predation by carabid beetles. In: HOLLAND, J.M. (Ed.). The agroecology of carabid beetles. Andover: Intercept, 2002. p.215-229.

TRANI, P.E.; TIVELLI, S.W.; BLAT, S.F.; PRELA-PANTANO, A.; TEIXEIRA, E.P.; ARAÚJO, H.S.; FELTRAN, J.C.; PASSOS, F.A.; FIGUEIREDO, G.J.B.; NOVO, M.C.S.S. Couve de folha: do plantio à pós-colheita. Campinas: IAC, 2015. 36p. (Technical Bulletin, 214). Available from: <http://www.iac.sp.gov.br/publicacoes/ publicacoes_online/pdf/BoletimTecnico2 14.pdf >. Access on: Mar. 162018.

VENZON, M.; TOGNI, P.H.B.; AMARAL, D.S.S.L.; REZENDE, M.Q.; FONSECA, M.C.M.; MARTINS, E.F. Manejo agroecológico de pragas. Informe Agropecuário, Belo Horizonte, v.36, p.19-30, 2015.

VILELA, N.J.; LUENGO, R.F.A. Produção de hortaliças folhosas no Brasil. Campo \& Negócios, 2017. Available from: <http:// www.revistacampoenegocios.com.br/producao-de-hortalicasfolhosas-no-brasil>. Access on: Jun. 252018.

WOJCIK, D.P.; ALLEN, C.R.; BRENNER, R.J.; FORYS, E.A.; JOUVENAZ, D.P. Red imported fire ants: impact on biodiversity. American Entomologist, v.47, n.1, p.16-23, 2001. https://doi. org/10.1093/ae/47.1.16 